\title{
Supporting Polish-Ukraine: A case study on the Afrikaans churches' reaction to communism
}

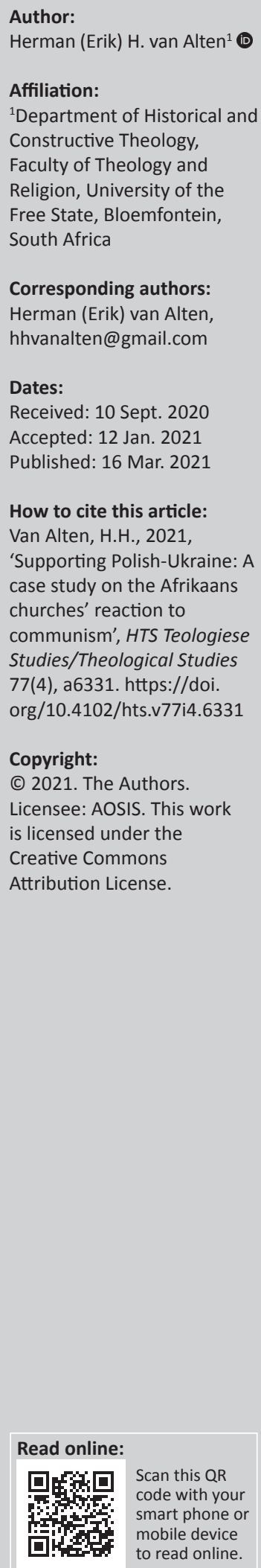

This article explores the role of the Afrikaans sister churches during the initial stages of the fight against communism. After initially sketching the relations between South Africa and Russia until the Bolshevik Revolution of 1917, focus is placed on a narrow case of financial support from the side of the Reformed Church in South Africa (the GKSA) via the Reformed Churches in the Netherlands towards the reformed movement in Polish-Ukraine during the 1930s and 1940s. Through the use of primary sources, this small historical cross-section illustrates how the GKSA, in cooperation with the other Afrikaans churches, fought the battle against communism during these initial stages. It also highlights the motivations that drove them. The sources reveal that the GKSA was not only concerned about the Reformed movement in far-away Polish-Ukraine, but that there was also a healthy measure of self-preservation and self-interest involved, protecting South Africa and its Christian population from the influence of communism by subtly promoting Calvinism as a formative paradigm for Afrikaner nationalism.

Contribution: This article contributes to a better understanding of the relations between Reformed Churches in South Africa and Eastern Europe during the first half of the 20th century, as well as to the role of the churches in fighting what it perceived as dangerous ideological influences.

Keywords: GKSA; Polish-Ukraine; Russia; Soviet Union; communism; Afrikaner Calvinism; Calvin; institutes.

\section{Introduction}

Eastern Europe and South Africa have experienced two very different traumatic epochs during the 20th century (communism and apartheid, respectively), but on several tangible levels, these epochs were connected. On the one hand, they were connected through the voluntary association with communism of organisations such as the South African Communist Party ${ }^{1}$ and to a lesser degree, the African National Congress, whose activities were intricately linked to the worldwide communist movement. ${ }^{2}$ On the other hand, these epochs were connected involuntarily, it should be stressed - as the white minority government (especially after the National Party victory of 1948), as well as several Afrikaner cultural institutions (e.g. the Ossewa-Brandwag and the Afrikaner Broederbond) and the Afrikaans sister churches ${ }^{3}$ felt compelled to wage a conscious campaign against communism and its main instigator, the Soviet Union (Visser 2004).

In this article, the role of the Afrikaans sister churches in the fight against communism will be explored. This will be done by focusing on a narrow case of financial support from the side of the Reformed Church in South Africa (GKSA) towards the Reformed movement in Polish-Ukraine ${ }^{4}$ during the 1930s and 1940s. Through the use of primary sources, this small historical cross-section will both illustrate the seriousness with which the Afrikaans churches fought the battle against communism and this article highlights the motivations that drove them. Before jumping into the subject matter, though, it will be worthwhile to get a sense of the relationship between South

1.Founded in 1921 and called the Communist Party of South Africa (CPSA) until its dissolvement shortly before the implementation of the 1950 Suppression of Communism Act; it was re-launched as the South African Communist Party (SACP) in 1953.

2.From its inception, the Communist Party of South Africa was part of the Communist International (Comintern). In 1928 Comintern even accepted a resolution for the CPSA to adopt the 'Native Republic' thesis which stipulated that South Africa was a country belonging to the natives (for the English translation of this resolution, see https://www.marxists.org/history/international/comintern/sections/ sacp/1928/comintern.htm, viewed on 22 April 2020).

3.The Nederduitse Gereformeerde Kerk (abbreviated NGK), the Nederduitsch Hervormde Kerk (abbreviated NHK) and the Gereformeerde Kerke (abbreviated GKSA).

4.In the period between WWI and WWII, most of what today is known as Western Ukraine belonged to Poland and was known as Eastern Galicia, whilst Eastern Ukraine belonged to the Soviet Union. However, the term Polish-Ukraine is used in this article, as this is the name used in the primary sources. 
Africa and Russia before the advent of communism as manifested in the Bolshevik Revolution of 1917. ${ }^{5}$

\section{South Africa and Russia before 1917}

In a very informative article, entitled Russia and South Africa before the Soviet Era, A.B. Davidson describes the relationship between Russia and South Africa from the mid-17th century (starting with Jan van Riebeeck's arrival in 1652) to the beginning of the 20th century. His description paints a picture of a growing relationship, reaching its pinnacle in the Russian involvement in and fascination with the cause of the Boers in the Anglo-Boer War. In this section 'South Africa and Russia before 1917', only a few aspects will be highlighted.

During the first 200 years (from 1652 to roughly 1850), contacts were mainly a result of the strategic position of the Cape of Good Hope on the trade route to the East, which even Russian ships had to pass in order to reach their Asian territories. Docking for repairs and fresh produce at the Cape of Good Hope gave many Russians the chance to set foot on African soil for the first time. V.M. Golovnin's Detained in Simon's Bay ${ }^{6}$ and I.A. Goncharov's At the Cape of Good Hope were a result of these visits and became the leading accounts through which readers back in Russia were informed about life at the southern tip of Africa (Davidson 2013:13-15).

Three events during the second half of the 19th century are worth mentioning. The first is the visit of Grand Duke Alexei (son of Tsar Alexander II, who ruled from 1855 to 1881) to Cape Town in 1872, where he was received with great pomp and splendour during his 3-week stay (Davidson 2013:1618). The second is a fascinating letter, dated 10 November 1886, from the secretary of the Pondo chief Mqikela, asking for the Tsar's assistance against British exploitation (Davidson 2013:18-20). We can only speculate why an African tribal leader would ask for the Russian Tsar's assistance. Most probably the fact that General George Cathcart, Governor of the Cape from 1852 to 1853 and hated by many, was killed by the Russians in the Crimean War (1853-1856), had something to do with this. The following words from Zakes Mda's novel, The Heart of Redness, seem to support this suspicion (Mda 2000): ${ }^{8}$

We all remember how the news of the death of Cathcart spread like wildfire, with universal jubilation and impromptu celebrations. People for the first time heard about the Russians. And while the British insisted that the Russians are as white as themselves, the AmaXhosa knew that it was a lie. The Russians were black. They were the spirits of the AmaXhosa soldiers who had died in various wars against the British colonisers ... (p. 70)

5.I realize that Russia is not a synonym for the Soviet Union or for communism. However, it is undeniable that Russia would come to play the dominant role in the Soviet Union and also formed the base from which communism would be spread throughout the world. Also keep in mind that the term 'Bolshevism' was used for quite some time instead of - and later as synonym of - 'communism'.

6.The English translation was published in 1964, 150 years after the first Russian edition (Golovnin 1964).

7.An abbreviated chapter of this book was later published in English in his nove (Goncharov 1960).

8.Mda (2000). Keep in mind that the Pondo were a part of the Xhosa people groups.
The third noteworthy event was that, during the second half of the 19th century, the first substantial wave of Russian immigration had arrived in South Africa. Census results show that the number of Russian émigrés grew from 82 in 1875 to 1092 in 1891, to 12137 in 1904 . The majority of these émigrés were Jews fleeing from anti-Semitic persecutions in Russia (Davidson 2013:22-23).

In a different work, entitled The Russians and the Anglo-Boer War, Davidson - in collaboration with I. Filatova - wrote extensively about Russia's preoccupation with the AngloBoer War (Davidson \& Filatova 1998). Not only did 225 Russian volunteers come to fight on the side of the Boers (which made it one of the largest volunteer groups), and not only did the Russo-Dutch ambulance as well as another Russian medical detachment serve in South Africa during the war, but in Russia itself 'Boerophilia' reached pitch fever. As Davidson $(2013)^{9}$ writes:

Thousands of articles and hundreds of books and pamphlets about the war and about the Boers were published in Russia in the first years of the twentieth century. A collection of most important of the Russian documents and contemporary publications on the war, published in 2012, consists of 13 volumes, about 400 pages each. Books by Boer politicians were translated into Russian. A folk song, 'Transvaal, Transvaal, My Country', was sung everywhere. It became the most popular Russian song and the only folk song ever about a foreign country. Theatres showing plays about the war were full to the brim ... Russian villages, streets, restaurants and pubs were named after Boer heroes or places in South Africa. (pp. 24-28)

Even after the war, several delegations of Boers approached Russia for assistance, none of which was successful (Davidson 2013:28-29; Ferreira 1991). Diplomatic relations (officially established in 1898 with the Transvaal) was, however, strengthened and expanded after the war. This manifested in trade, mining, culture and academic ties.

The picture painted above, though brief, clearly gives the impression of a growing affinity between Russia and South Africa from the middle of the 17th century, and more specifically between Russia and the Boers in the decades leading up to - and the years following after - the AngloBoer War. There is no indication during this period that would explain the mistrust and negative propaganda that would gradually take a grip on the South African government and the broader Afrikaner society (including the media and the Afrikaans sister churches) after the Russian Revolution.

\section{The reaction after 1917}

... for the greater part of the first two decades of the twentieth century no serious attention was given in South African literature to the phenomenon of socialism or communism (Visser 2004:2). A few socialist parties and societies were formed during this time, and the first South African reference

9.A rendition of the song 'Transvaal, Transvaal' can be found on www.youtube.com/ watch?v=m0sb4cLV6a8, viewed on 17 June 2020. Proof of this Russian interest in watch?v=m0sb4cLV6a8, viewed on 17 June 2020. Proof of this Russian interest in
the Anglo-Boer War can still be seen today in the ZAR-hall at the Kruger House in Pretoria. 
to communism appeared in 1910 in the socialist weekly Voice of Labour, but not much attention was paid to these upcoming ideas. Indicative of this, is D.F. Malan's speech about socialism at a meeting of the Graaff-Reinet Literary Society in 1913. Malan distinguishes between two forms of socialism, namely anarchism and Christian socialism. The former (which would include communism) he adjudges to be 'comparatively insignificant and ... need not further be discussed' (Van Deventer 1991:2). Even after the Bolshevik Revolution of 1917, someone of the stature of J.B.M. Hertzog, whilst acknowledging the deficiencies, could nonetheless talk about the virtues of Bolshevism, saying that at heart it is 'de wil van het volk om vry te zijn, zelf te regeren en niet aan ' $n$ vreemde veroveraar onderwerpen te zijn'. Van Deventer (1991:6) convincingly shows that Hertzog's statement should be understood against the background of the precarious constitutional position of the Union of South Africa within the British Empire and the resistance against South Africa's involvement in WWI. An interesting exception to the lack of critical attention for Bolshevism and communism during the first two decades of the 20th century is two brief articles by J.D. du Toit (Totius) in Het Kerkblad of April and May 1919. These articles make clear that, at that stage, Bolshevism is still a fairly novel phenomenon in South Africa, and Totius' description of it is mostly limited to its manifestation in Europe and Russia. He is only able to provide the reader with one or two - fairly innocuous - examples of the presence of Bolshevism in South Africa. In the first article (dated 01 April 1919), Totius refers to two Russians who lectured on Bolshevism in the city hall of Johannesburg. In the second article (dated 01 May 1919), he again refers to the two Russians and adds the Johannesburg tram-strike (Du Toit 1977:85-91).

It is only after the Rand Revolt of 1922 that a gradual increase in anti-communist rhetoric and writing from the side of the government and the media could be observed. J.C. Smuts, for example, blamed the revolt on forces of violence and anarchy, whom he identified as international communists who had come from abroad and were opposed to the traditions of South Africa. These communists, aiming to establish a Soviet republic in South Africa, were supported by local people (Van Deventer 1991:14). This was echoed a year later by journalist Chilvers (1923:11-19) in his pamphlet The Menace of Red Misrule, in which he expressed his concern at 'how earnestly the South African "Reds" are endeavouring ... to reproduce Russian conditions in this country'. As Afrikaner nationalism developed in the next two decades and the race-question became more and more pertinent, the Native Administration Bill of 1927 and the Riotous Assemblies Amendment Bill of 1930 became important tools to undermine any communist propaganda. This propaganda was seen as a threat to relations between white and black people, coming not so much from the side of black people but from the side of 'white communist agitators who could incite blacks against whites' (Visser 2004:3). Anti-communist literature, produced during the 1930s, focused on the perceived communist aims of overthrowing the existing world order, creating a black republic and destroying patriotism, the family and religion (Diederichs 1938; Oosthuizen 1938).
It was this last aspect in particular - corresponding with the avowed atheism of international communism - that put the Afrikaans churches on high alert from the 1930s, and led to a host of studies, reports and conferences. ${ }^{10}$ It is within this context and against this background that we zoom in on the GKSA's support for the Christians and churches in Polish-Ukraine.

\section{The Reformed Church in South Africa and Polish-Ukraine}

The GKSA's support for the Reformed movement in PolishUkraine has a very distinct Dutch connection. In fact, it seems that all of the GKSA's support went through their Dutch connections, with no proof of any direct contact with the Ukrainian churches or Ukrainian individuals. This is an important fact to keep in mind.

In or around 1933, the Dutch Committee for Reformed Ukraine, of which rev. F. Dresselhuis was the secretary and driving force, ${ }^{11}$ was started in the Netherlands to support the Reformed movement in Polish-Ukraine. This was not an ecclesiastical committee, but a private initiative that succeeded in having the Heidelberg Catechism translated into Ukrainian and in sponsoring a Ukrainian theological student for study at the Free University in Amsterdam (Acta 1933:307). Three years later, in 1936, we again came across the name of rev. Dresselhuis, this time not in the Netherlands, but in the Acts of Synod of the GKSA. Rev. Dresselhuis' letter is one of the two letters (the other coming from the Consistory of Rustenburg and addressing the same issue) that features in an overture from the Regional Synod of Transvaal to the General Synod of the GKSA. In this overture, a request is made for financial support for a translation of the abbreviated Institutes of Calvin (by the Dutch theologian B. Wielenga) into Ukrainian, for the benefit of the Reformed movement in Polish-Ukraine (Handelinge 1936:138; Wielenga 1934).

From this, it can be deduced that somewhere between 1933 and 1936, contacts were established between the Dutch Committee for Reformed Ukraine and the Reformed Church in Rustenburg (or at least some of its members). These contacts resulted in the letters on the table of the Regional Synod of Transvaal, which in turn led to the overture addressed to the General Synod meeting in 1936. The General Synod approved the request and appointed as deputies the same persons who served on the existing committee in Rustenburg: rev. D.N. Kotze (from the Reformed Church in Rustenburg, chairman), rev. P.G.W. Snyman (from the Reformed Church in Krokodilrivier, secretary and treasurer) and rev. A. Duvenage (from the Reformed Church in Koster, member). In addition, the Synod advised deputies to write an article in Die Kerkblad to ask for voluntary donations for the intended translation project (Handelinge 1936:138).

10.Visser (2004:7-11) gives a helpful, though brief, overview of the reaction from ecclesiastical side.

11.In an article in the Dutch newspaper, De Volkskrant, his daughter testified how her father travelled through Ukraine during the thirties to distribute the translated Heidelberg Catechism; viewed 24 April 2020, from https://www.volkskrant.nl/ nieuws-achtergrond/alle-verdriet-over-mijn-vader-kwam-eruit-huilen-huilen $\sim$ b8a nieuws-achtergrond/alle-verdriet-over-mijn-vader-kwam-er
2a71d/?referer=https $\% 3 \mathrm{~A} \% 2 \mathrm{~F} \% 2 \mathrm{Fwww}$.google.co.za\%2F. 
An article was indeed published in Die Kerkblad on 17 June 1936. After explaining the background for the article (the same background as already related above), the author - rev. Snyman - continues by describing the needs of the Reformed movement in Ukraine (Snyman 1936:135-136). He does this by giving a brief overview of the history of Ukraine and of Christianity in this part of the world. What is striking in this overview is the recurrence of Bolshevism as a destructive force, both in Russian-Ukraine (Eastern Ukraine) and PolishUkraine (Western Ukraine) (Snyman 1936):

Na verdrukking deur die Tartare, is Oekraïne reeds in 1668 verdeel in 'n Oostelike Oekraïne onder Russiese beheer en Westelike Oekraïne onder Poolse beheer. Oostelike Oekraïne het steeds onder Russiese beheer gestaan en is eers onderdruk wat hulle taal en kultuur betref en sedert die Bolsjewiste in 1918 aan bewind gekom het is hulle veral in hulle godsdiens vervolg.

In 1763 egter, het daar 'n oplewing gekom ... Wat die herlewing ook mag uitgewerk het, in Russies-Oekraïne is deur die Bolsjewiste alles verwoes. (p. 136)

Twice the author makes a significant historical leap from a date in either the 17th century or the 18th century to the advent of Bolshevism in the beginning of the 20th century and its detrimental effect on the faith in Russian-Ukraine. It seems that, for the author, Bolshevism is the defining factor for the situation of the church in Russian-Ukraine at the time of writing. The situation in Polish-Ukraine is very different - here the author can testify to God's work in raising a Reformed movement since 1925. But its geographical proximity to Bolshevistic Russia makes support of this movement imperative: 'Dit is hierdie Gereformeerde rigting in Pools-Oekraine wat ons moet steun daar aan die grens van Bolsjewistiese Rusland' (Snyman 1936:136). The author identifies three main needs of the Reformed movement in Polish-Ukraine: meeting places, trained pastors and Reformed literature. It is the author's request that consistories and individuals consider supporting this third need, in particular the translation of the abbreviated Institutes of Calvin.

In addition to the article in Die Kerkblad, the deputies' steps can be traced in several other publications between 1936 and the following General Synod in 1939. After having funded the translation of the abbreviated version of Calvin's Institutes into the Ukrainian language (clearly the churches heeded the call of deputies in the article in Die Kerkblad), the Dutch Committee requested deputies to test the waters in South Africa for a broader support of the Reformed movement in Ukraine. For this purpose, rev. Snyman wrote an article (dated 04 March 1938), which was sent to all the congregations of the NGK, NHK and GKSA (Handelinge 1939:195-196). It was subsequently also published in Die Kerkbode (magazine of the NGK) on 23 March 1938, as well as in Die Hervormer (magazine of the NHK) on 27 April 1938b. ${ }^{12}$ After the

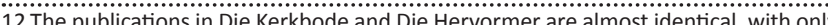
some omissions in Die Hervormer. In a postscript, the editor of Die Hervormer gives as reason for these omissions: 'Ons het ' $n$ deel van die brief moes skrap weens as reason for these omissions: 'Ons het ' $n$ deel van die brief moes skrap weens gebrek aan plaasruimte. As die ondertekenaar ' $n$ interkerklike kommissie vir hierdie
goeie saak verlang, moet hy hom wend tot die bevoegde kerklike outoriteite'. Most introduction, the author proceeds to describe the need (Snyman 1938a): $:^{13}$

Maar waar die noodtoestand van Pools-Oekraïne (Herv. beweging) letterlik skreiend roep om hulp, daar het sowel die Nederlandse Komitee met prof. Besselaar, ons vertrouensman, asook die deputate van die Geref. kerke van Suid-Afrika, die noodsaaklikheid gevoel van 'n interkerklike samewerking in Suid-Afrika tot steun van die Hervormingsbeweging in Oekraïne. U moet begryp, Mnr. Redakteur, dat Pools Oekraïne reg teenoor Russies Oekraïne lê waar die Bolsjewisme se invloed die bestaan van die Christendom bedreig. (p. 531)

The author continues to describe the dire situation of the Reformed movement in Polish-Ukraine - both in relation to the lost glory of its Reformed past, ${ }^{14}$ and in relation to the current suppression by Roman Catholic and Greek Catholic churches. However, the primary and fundamental need of the Reformed movement in Polish-Ukraine, as deemed by the author, has by then already been etched in the mind of the reader: the geographical position of Polish-Ukraine with regard to the sphere of influence of Bolshevism. This need was highlighted by addressing the editor in the first person: 'Mnr. Redakteur'.

Something similar can be seen from an annual report that was published in Die Kerkblad on 16 November 1938 under the heading 'Van die Oostelike Front'. Rev. Dresselhuis was the author. In it, we read the following (Dresselhuis 1938):

Vir iemand wat egter bekend is met die arbeid van die Sending, is dit vanselfsprekend dat slegs een belang hier geld, nl. dié van die stigting van die ryk van God onder die gelowiges in Christus, deur die prediking van die Evangelie. Want waarlik, die eerste linie wat gevorm is teen die strydende Bond van die godloses, bevind homself op Oekraïnse bodem in Oos-Pole. En alle Evangeliese gemeentes wat daar langs die grense ontstaan het, is daar gestig nie volgens 'n voorbedagte plan nie, maar heel toevallig het hulle tot openbaring gekom. En vanaf hierdie Evangeliese strydfront verbrei die lig van die christelike waarheid hom na die ooste, binne die Oekraïnse volk. Ons hou onsself daarvan oortuig dat die tyd nie meer ver af is nie dat ook die Oekraïnse volk wat homself tans nog bevind in die geweld van die Sowjet, die waarheid van die Evangelie sal aanneem en homself tot God sal bekeer. (pp. 7-8)

The author makes clear that there is only one concern: the establishment of the Kingdom of God through the preaching of the Gospel. But the reason given for this primary concern is enlightening: Polish-Ukraine is considered to be the first line of defence against 'die strydende Bond van die godloses', which is undoubtedly a reference to the League of Militant Atheists. This League was the nominally independent organisation created in 1925 by the Communist Party to promote atheism. It reached its zenith in the 1930s through its

of what has been omitted, therefore, has to do with the proposed cooperation, for which the editor refers the author to the appropriate ecclesial bodies.

13.For the article in Die Hervormer, see https://archive.org/details/ diehervormer00unse_ly2/page/12/mode/2up, viewed on 24 April 2020.

14.'Met die 16 e eeuse Reformasie het onder invloed van Kalvyn se vriende, Johannes a Lasco en Radziwil, die Kalvinistiese Reformasie in Wolhynië, Oekraïne en omstreke wortel geskiet en sowat 50 gemeentes het daar gefloreer' (Snyman 1938a:531). For more on the 16th century Reformation in Eastern Europe, see Maag (ed. 1997); Bem (2020). For more on Calvin's correspondence with reformers in Eastern Europe, see Muller (2015:21-55). 
newspaper Bezbozhnik [The Godless] and large quantities of antireligious pamphlets and posters. The League was the centre of all efforts to bring atheism to the masses (Peris 1998:2). Against - and as a result of - this atheistic endeavour, rev. Dresselhuis considers the establishment of the Kingdom of God as the primary concern. He describes the evangelical congregations that have sprung up along the border between Polish-Ukraine and Soviet Russia, as the battlefront with Soviet atheism. And he has no doubts that this battle will lead to victory for the truth of the Gospel.

At the next Synod of the GKSA, meeting in Bloemfontein in 1939, deputies report about their work. Here they also request permission from the Synod for what has, in essence, already started when they asked for the support from the NGK and NHK in 1938 (Handelinge 1939):

$\mathrm{U}$ deputate vra vir hierdie verdere optrede en handelinge, die Calvinistiese Protestantisme aan die Oostelike Front ten goede, U Eerw's se goedkeuring en beveel aan, dat hierdie goeie saak van 'n Calvinistiese Protestantisme in Pools Oekraïne, wat in die 16e eeu onder a Lasco en Radziwil met groot seën ingang gevind het, maar deur die Contra-reformasie verwoes is, en tans by sy herlewing na drie-honderd jaar, deur die Roomse kerkgroepe heftig bestry en deur die Bolsjewisme aan die Oostergrens bedreig word, - met vrywillige gawes in samewerking met die Ned. Geref. Kerke in S.A. verder gesteun word. (pp. 194-197)

Once again, Bolshevism (together with the Roman Catholic Church - the dominant church in Poland, of which PolishUkraine was a part) is mentioned as an existential threat to the survival of the reviving Reformed movement (twice called Calvinistic Protestantism) in Polish-Ukraine. Deputies receive permission to use the funds that have been raised for the benefit of the Reformed movement in Ukraine, depending on favourable reports from the Dutch committee (Handelinge 1939:197).

What makes the deputies' report even more interesting is that the same Synod had earlier dealt with an overture from the consistory of Brakpan about communism (Handelinge 1939:100). In this overture, the Synod is asked to request the government to silence the dangerous agitators and to ban communist literature. This request comes in light of the everexpanding communist propaganda in the country, especially amongst the coloured people ('kleurlinge') and black people ('naturelle'). Synod is also asked to request the cooperation of the other churches in the country. At the same time, Synod decides to deal with an overture from Classis Pretoria about the desirability of Christian labour organisations and the need for believers to organise themselves on a Christian-National basis (Handelinge 1939:102). Two commissions are appointed to deal with these two related overtures. In reporting back, the commission dealing with Brakpan's overture about communism puts a substantial manifest on the table, in which they warn against the Red World-revolution that poses " $n$ gevaarlike bedreiging van die heerskappy en voogdyskap van die blankes in Suid-Afrika, wat die christelike sendingwerk ondermyn en vrugteloos maak'. The manifest makes a series of appeals on the church, the white population of South Africa, the government and the political parties, respectively. ${ }^{15}$ Finally, this commission recommends to Synod to publish the manifest in Die Kerkblad and in the daily newspapers to appoint deputies to meet with the government and to organise an Anti-Communist Congress in cooperation with other churches (Handelinge 1939:100-102). The recommendations of the commission dealing with Christian labour organisations overlap and correspond to a large extent with those of the commission dealing with communism (Handelinge 1939:102-103). The Synod accepts all the recommendations, acknowledging 'die ontwrigting van ons Chr. Nasionale volksbestaan deur die kommunistiese propaganda' (Handelinge 1939:103).

Throughout the 1940s, the activities of the deputies for support of Polish-Ukraine, appointed in 1936, can be traced in the Acts of Synod, but nothing new comes to light. In the Acts of 1942 and 1945, deputies' reports are short - only relating that, because of the war (WWII), they have not been able to transfer the collected money to the Dutch committee (Handelinge 1942:140-141, 1945:88). The Acts of 1949 merely note that the money has been transferred (Handelinge 1949:153). In the same period, the stance against communism is intensified, which indicates that the prevalence of this ideology in South Africa had increased. But this is the material for further research.

The picture emerging from this investigation into the primary sources about the GKSA's involvement with and support for the Reformed movement in Polish-Ukraine is one that shows several layers. The most obvious layer is one of genuine concern for fellow Reformed Churches and believers in Eastern Europe. This concern is expressed through fundraising - not only within the GKSA but in cooperation with the other Afrikaans churches - for the dire needs (meeting places, trained pastors and Reformed literature) of the Ukrainian churches. However, there is a deeper level that expresses not only concern for the churches in Polish-Ukraine but even more so for the Afrikaans churches. This 'selfinterest' is highlighted by the fact that there is no proof of personal contacts between individuals or churches within the GKSA and individuals or churches in Polish-Ukraine - all of the contacts were conducted through the GKSA's Dutch partners. This raises the question: what was the real motivation for supporting these far-away and unknown brothers and sisters? It seems that, through its genuine support for the needs of the churches in Polish-Ukraine, the Synod of the GKSA had its eye on a bigger goal: the fight against Bolshevism. This fight, which is a recurring theme in all the correspondence about this matter, is partly waged through support for the churches in Polish-Ukraine. By strengthening the first line of defence against Bolshevism that is, the Reformed Churches on the border with Soviet Russia - the GKSA, and with it the other Afrikaans churches, was fighting against an ideology that had come very close to home during the 1930s (as shown by the overture about 15.In 1943, De Toit (Totius) (1977:100) would lament that this manifest, written so
powerfully and with so much conviction, lies buried in the acts of synod, Totius Versamelde Werke 7 . 
communism at the Synod of 1939). In some sense, the GKSA itself, during the 1930s, became a first line of defence in this fight, as the 1940s would show an exponential increase of anti-communist writings, lectures and conferences from the ranks of the Afrikaans churches (Visser 2004:7-11). With their support for Polish-Ukraine in the 1930s, the GKSA was pioneering a fight that would increase in intensity in the subsequent decades. However, it was not only a fight against something (Bolshevism), it was at the same time a fight for something else. And that something, Afrikaner Calvinism, entered the stage in roughly the same period. In order to understand this connection, we have to return to the initial translation project.

\section{A Ukrainian translation of Calvin's Institutes}

Sufficient funds were raised by the Afrikaans churches to pay for the translation of John Calvin's Institutes, as abbreviated by B. Wielenga. Julian Szulha took upon himself the mammoth task of translating this work into Ukrainian - he was the same Ukrainian theological student, already referred to above, who was at that stage supported by the Dutch committee to study in the Netherlands. By the time the GKSA Synod met in 1939, the translation was ready, and the deputies expected to soon receive a complimentary copy of it (Handelinge 1939:195). When I started searching for this translation, I found it on a website belonging to the Evangelical Reformed Seminary of Ukraine, on which Reformed material - translated into Russian or Ukrainian, or originally written in one of these languages - is published for perusal by any interested person. ${ }^{16}$ The Ukrainian cover page indeed recognises the contribution of the Reformed Church in South Africa, and as the places of publication Cape Town is mentioned, together with Amsterdam (the Netherlands) and Kolomyia (a city in south-western Ukraine) (Calvin 1939).

Funding a translation project for the benefit of the Ukrainian churches, however, was in itself an interesting choice. The reader should not forget that, by 1936, barely 3 years had passed since Joseph Stalin orchestrated the death by hunger of the Ukrainian people, the so-called Holodomor. ${ }^{17}$ It is estimated that some 10 million people died during this manmade famine. Thus, a lack of pastors, a need for Reformed literature and a desire for adequate meeting space were not the only - and probably not the most pressing - needs which the Reformed movement in Polish-Ukraine had to deal with. Why did the GKSA not offer financial support to a nation in the midst of a devastating famine? Why did the GKSA not offer more tangible and concrete support? I want to propose that funding a translation of, specifically, Calvin's Institutes in many ways corresponded with the GKSA's fight against communism.

16.See https://reformed.org.ua/3/968/Calvin. According to Dr Dmytro Bintsarovskyi who himself is a native Ukrainian speaker, 'the quality of translation is weak, and the Ukrainian language is just terrible for ears of contemporary Ukrainians'. However, he agrees that this does not detract from the historical value of this translation.

17.See Snyder (2010); see also the movie, Mr Jones (2019), which tells the true story of a journalist who travels through Ukraine in 1933 to cover this famine.
The 1920s not only saw the rise of communism in South Africa, with the concomitant narrative of the dangers and risks that it posed to the Afrikaner society, but it also saw the rise of a different narrative: Calvinism and Calvinism of a very specific Afrikaner flavour. This narrative was used to make sense of the Afrikaner history and to defend it against outside forces.

\section{Afrikaner Calvinism}

According to this narrative, the Afrikaner founding fathers brought with them to the Cape the basic tenets of 17th century Calvinist thought. These tenets became fixated in the isolated frontier conditions of trekboer society; it provided much of the rationale for the Great Trek, that central event of Afrikaner history, whereby the Voortrekkers considered themselves to be chosen and covenanted people with a divine mandate to leave the house of slavery and travel to the Promised Land, whilst smiting the heathen nations on their way. Eventually, this became the justification for racial inequality during the 20th century (Du Toit 1983:920). Du Toit (1983:920), however, writes that this 'cluster of constructs ... constitutes a historical myth that I call the "Calvinist paradigm" of Afrikaner history'. He clearly shows that this paradigm was, firstly, not present before the second half of the 19th century, and secondly, was not created by Afrikaners themselves, but by people (some even being enemies of the Afrikaner) who wrote about the history of the Afrikaner, in particular the missionary-explorer David Livingstone. Britz (1994:196-206) has subsequently shown that Afrikaners only started to appropriate Calvinism as a paradigm for making sense of the Afrikaner history during the latter part of the 19th century in order to counter British-imperial historiography. However, in the historiography of this time, the concept 'Calvinism' was still used sparingly and incidentally, which shows that by the end of the 19th century, Afrikaners did not yet think of themselves primarily as Calvinists. During the early 20th century, and more specifically during the 1920s, this changes. During this time, the concept of 'Calvinism' and 'Calvinistic' is expanded not only to indicate a doctrinal origin but to cover a wide range of religious, cultural and political expressions (Britz 1994:199-200). Gie (1924), in his Geskiedenis van Suid-Afrika of ons verlede, articulates the new paradigm when he writes that 'die eerste staatstigters' brought with them:

$[D]$ ie krag van die Germaan, gewortel in die Kalvinisme. Dit was Kalvyn se leer van die absolute almag van God wat staal in die bloed van die Geuse gebring het; dieselfde leer sou ook in SuidAfrika vir hulle nakomelinge ' $n$ houvas en ' $n$ inspirasie wees. (p. 53)

For Gie and subsequent authors, Calvinism is not merely a casual reference, but a description of the meaning and dynamics of Afrikaner existence and spirit.

Both Du Toit (1983:921) and Britz (1994:206-207) acknowledge that, although Calvinism as paradigm has often been assumed rather than proven from the sources, its existence in Afrikaner historiography can nonetheless not be denied. It is this Calvinist paradigm that gave a crucial impetus to Afrikaner nationalism from the 1920s. It helped the Afrikaner 
to give meaning to their history and existence, also against negative influences from the outside.

In view of this particular understanding of Calvinism as a formative paradigm for Afrikaner nationalism since the 1920s, it might be worthwhile to see whether traces of its influence also worked through in the sources describing the GKSA's support for Polish-Ukraine.

The report 'Van die Oostelike Front', published in Die Kerkblad on 16 November 1938, contains a few documents that were also included in the translation of Calvin's Institutes, amongst which was a word to the reader from professor G. Besselaar (Dresselhuis 1938:9). A few things are noteworthy from professor Besselaar's words to the reader. Firstly, professor Besselaar notices the worldwide significance and power of Calvinism, as Calvin's Institutes now become available to the believers in Ukraine, thanks to their brothers and sisters in South Africa. Secondly, and more importantly, professor Besselaar calls Calvin 'die eerste groot Voortrekker': 'Suid-Afrika, Oos- en Wes-Europa skaar in hierdie boek as vanself hulle agter Johannes Calvyn, die eerste groot Voortrekker, die groot Leier na Paulus, die Kerkvaders en die Konsilies' (Dresselhuis 1938:10). It is an intriguing word choice, which seems to say more about South Africa, whence the support for the translation came, than about the church in Ukraine for whom it was intended. Did professor Besselaar consciously connect John Calvin to the Great Trek?

In addition, in the GKSA Acts of Synod of 1939, the deputies twice use the phrase 'Calvinistic Protestantism' when requesting the approval of the Synod to support the churches on the Eastern Front. Take note how 'Calvinistic Protestantism' is juxtaposed both times with the threats on the Eastern Front:

$\mathrm{U}$ deputate vra vir hierdie verdere optrede en handelinge, die Calvinistiese Protestantisme aan die Oostelike Front ten goede, U Eerw's se goedkeuring en beveel aan, dat hierdie goeie saak van ' $n$ Calvinistiese Protestantisme in Pools Oekraïne, wat in die 16e eeu onder a Lasco en Radziwil met groot seën ingang gevind het, maar deur die Contra-reformasie verwoes is, en tans by sy herlewing na drie-honderd jaar, deur die Roomse kerkgroepe heftig bestry en deur die Bolsjewisme aan die Oostergrens bedreig word, - met vrywillige gawes in samewerking met die Ned. Geref. Kerke in S.A. verder gesteun word. (Handelinge 1939:196-197)

In the article published in Die Kerkbode (magazine of the NGK) on 23 March 1938, as well as in Die Hervormer (magazine of the NHK) on 27 April 1938, a similar juxtaposition can be seen. After describing the threat of Bolshevism to the church in Polish-Ukraine, the author continues:

Maar wat dit in Oekraïne nog erger maak is dit: Met die 16de eeuse Reformasie het onder invloed van Calvyn se vriende, Johannes a Lasco en Radziwil, die Calvinistiese Reformasie in Wolhynië, Oekraïne en omstreke wortel geskiet en sowat 50 gemeentes het daar gefloreer. Maar dadelik het die TeenReformasie deur die Jesuiete, dié reformasie in die kiem gesmoor, sodat die Protestantisme daar vroeg weer verdwyn het. (Snyman 1938a:531)
These traces might seem like breadcrumbs, but they do indicate that the GKSA's recognition of the Bolshevist threat was only one side of the coin. The same coin also had an important flipside: the reinforcement of Calvinism. And in view of the history of the Afrikaner during the 1920s, it was Calvinism of a very specific flavour.

\section{Conclusion}

According to the report 'Van die Oostelike Front', a representative of the Polish Sejm (parliament) posed the following question at a political meeting in Stepan (Polish-Ukraine, 1936): 'Waarom word daar EvangeliesGereformeerde gemeentes gestig langs die Horyn-rivier, wat die grens vorm tussen ons en Sowjet-Rusland? Wie het daaraan behoefte?' (Dresselhuis 1938:7). Little could this representative have known that thousands of kilometres away, his rhetorical question was answered emphatically by the GKSA. The primary sources show that the GKSA's sincere and brotherly financial support was at the same time intended to fight Bolshevism and promote Calvinism in South Africa. This little-known case of financial support for the churches in Polish-Ukraine gives us a small window into the initial skirmishes of what would become a full-blown battle in South Africa in the subsequent decades - against communism and for Afrikaner Calvinism. Further research should be done into how these initial skirmishes developed into the full-blown battle that it became, what the main theological motivations were for this battle, and whether the battle coincided with continued support for the churches in Polish-Ukraine and the Soviet Union.

\section{Acknowledgements Competing interests}

The author declares that he has no financial or personal relationships that may have inappropriately influenced him in writing this research article.

\section{Author's contribution}

H.H.v.A. is the sole author of this research article.

\section{Ethical considerations}

This article followed all ethical standards for research without direct contact with human or animal subjects.

\section{Funding information}

This research received no specific grant from any funding agency in the public, commercial or not-for-profit sectors.

\section{Data availability}

Data sharing is not applicable to this article as no new data were created or analysed in this study. 


\section{Disclaimer}

The views and opinions expressed in this article are those of the author and do not necessarily reflect the official policy or position of any affiliated agency of the author.

\section{References}

Acta, 1993, Acta der Generale Synode van de Gereformeerde Kerken in Nederland gehouden te Middelburg van 22 Augustus tot 8 September 1933, J.H. Kok, Kampen.

Bem, K., 2020, Calvinism in the Polish Lithuanian Commonwealth 1548-1648, Brill, Leiden.

Britz, R.M., 1994, 'Die begrip "Calvinisme" in die Afrikaanse geskiedskrywing. 'n Oorsigtelike Tipering', Skrif en Kerk 15(2), 196-218. https://doi.org/10.4102/ve. v15i2.1092

Calvin, J., 1939, Institutes of the Christian religion. Ukrainian translation by Rev. Julian Schulha, viewed 17 August 2020, from https://reformed.org.ua/3/968/Calvin.

Chilvers, H., 1923, The Menace of Red Misrule: Facts and figures for all, Johannesburg.

Davidson, A.B., 2013, Russia and South Africa before the Soviet era, viewed 17 August 2020, from https://papers.ssrn.com/sol3/papers.cfm?abstract_id $=2253209$.

Davidson, A.B. \& Filatova, I., 1998, The Russians and the Anglo-Boer War, 1899-1902, Human \& Rousseau, Cape Town.

Diederichs, N., 1938, Die Kommunisme. Sy teorie en taktiek, Bloemfontein.

Dresselhuis, F., 1938, 'Van die Oostelike front', Die Kerkblad, 16 November, pp. 7-10.

Du Toit, A., 1983, 'No chosen people: The myth of the Calvinist origins of Afrikaner nationalism and racial ideology', The American Historical Review 88(4), 920-952. https://doi.org/10.2307/1874025

Du Toit, J.D., 1977, Totius Versamelde Werke 7, Tafelberg-Uitgewers Bpk., Cape Town.

Ferreira, O.J.O., 1991, 'Genl. F.J. Pienaar. Die boer wat 'n Russiese protektoraat oor Suid-Afrika voorgestaan het', Scientia Militaria. South African Journal of Military Studies 21(4), 13-17. https://doi.org/10.5787/21-4-336

Gie, S.F.N., 1924, Geskiedenis van Suid-Afrika of ons verlede, Pro Ecclesia, Stellenbosch.

Golovnin, V.M., 1964, Detained in Simon's Bay: The story of the detention of the imperial Russian sloop Diana. April 1808-May 1809, Friends of the South African Library, Cape Town.

Goncharov, I.A., 1960, 'The Fregate Pallada: A Russian view of the Cape in 1853 , translated by NW Wilson from IA Goncharov's Fregat Pallada with additional notes by DH Varley', Quarterly Bulletin of the South African Library 15(2-4), 16(1), 63-70.
Handelinge, 1936, Handelinge van die 25ste Sinodale Vergadering van die Gereformeerde Gemeentes in Suid-Afrika, in sitting byeen te Bethulie, O.V.S. op Gereformeerde Gemeentes in Suid-Afrika, in
Donderdag, 5 Maart, 1936, en volgende dae.

Handelinge, 1939, Handelinge van die 26ste Sinodale Vergadering van die Gereformeerde Gemeentes in Suid-Afrika, in sitting byeen te Bloemfontein, O.V.S. op Woensdag 23 Maart, 1939 en volgende dae.

Handelinge, 1942, Handelinge van die 27e Sinodale Vergadering van die Gereformeerde Gemeentes in Suid-Afrika, in sitting byeen te Aliwal-Noord, Kaapland op Donderdag 12 Maart, 1942 en volgende dae.

Handelinge, 1945, Handelinge van die 28ste Sinodale Vergadering van die Gereformeerde Gemeentes in Suid-Afrika, in sitting byeen te Potchefstroom op 24 Januarie 1945 en volgende dae, Caxton, Pretoria.

Handelinge, 1949, Handelinge van die 30ste Sinodale Vergadering van die Gereformeerde Gemeentes in Suid-Afrika, in sitting byeen te Potchefstroom op 26 Januarie 1949 en volgende dae.

Maag, K. (ed.), 1997, The reformation in Eastern and Central Europe, Ashgate Publishing, New York, NY.

Mda, Z., 2000, The heart of redness, Oxford University Press, Cape Town.

Muller, R.A., 2015, 'Facing Poland: Calvin's Polish correspondence and the geography of reformation Europe', in J. Balserak \& R. Snoddy (eds.), Learning from the Past, pp. 33-56, Bloomsbury T\&T Clark, London.

Oosthuizen, A.J.G., 1938, Kommunisme en die Vakunies, Heidelberg.

Peris, D., 1998, Storming the heavens: The Soviet League of the Militant Godless, Cornell University Press, Ithaca.

Snyder, T., 2010, Bloodlands: Europe between Hitler and Stalin, Vintage Books, London.

Snyman, P.G.W., 1936, 'Oproep om steun vir Gereformeerd Oekraïne', Die Kerkblad, 17 Junie, pp. 135-137.

Snyman, P.G.W., 1938a, 'Oproep om steun vir Gereformeerd Oekraïne', Die Kerkbode, 23 Maart, p. 531.

Snyman, P.G.W., 1938b, 'Pools Oekraïne', Die Hervormer, 27 April, pp. 13-14.

South African Communist Party Documents, 1928, The South African question, viewed 22 April 2020, from https://www.marxists.org/history/international/comintern/ sections/sacp/1928/comintern.htm.

Van Deventer, A., 1991, 'Afrikaner nationalist politics and anti-communism 1937-1945', Unpublished Master's thesis, viewed 17 August 2020, from https:// scholar.sun.ac.za/handle/10019.1/69081.

Visser, W., 2004, 'The production of literature on the "Red Peril" and "Total Onslaught" in twentieth-century South Africa', Historia 49(2), 105-128.

Wielenga, B., 1934, Johannes Calvijn's Institutie of Onderwijzing in den Christelijken Godsdienst verkort weergegeven door Dr B. Wielenga, J.H. Kok, Kampen. 